\title{
Genesis of Clastic Dykes and Soft-Sediment Deformation Structures in the Mamfe Basin, South-West Region, Cameroon: Field Geology Approach
}

\author{
Bokanda Ekoko Eric $(\mathbb{D}$, Ekomane Emile, Eyong John Takem, Njilah Isaac Konfor, \\ Ashukem Ethel Nkongho, Bisong Rita Ndige, and Bisse Salomon Bertrant \\ University of Yaoundé I, Yaoundé, Cameroon \\ Correspondence should be addressed to Bokanda Ekoko Eric; eric_ekoko@yahoo.com
}

Received 1 September 2017; Revised 25 November 2017; Accepted 31 December 2017; Published 6 February 2018

Academic Editor: Marco Bonini

Copyright (C) 2018 Bokanda Ekoko Eric et al. This is an open access article distributed under the Creative Commons Attribution License, which permits unrestricted use, distribution, and reproduction in any medium, provided the original work is properly cited.

\begin{abstract}
This paper aims to investigate the genesis of clastic dykes and soft-sediment deformation structures in the Mamfe Basin, South West-Region, Cameroon. Results from this study portray the following: (1) The clastic dykes are extrusive and were generated from preexisting soft-sediments that penetrate fissures caused by seismic activity. It can be concluded that clastic dykes originate from seismic shacking, probably induced by volcanic-tectonic activity and magmatic dykes that cut across the Precambrian and Cretaceous formations of the Mamfe Basin. (2) The soft-sediment deformation structures (flexures, sheared foliations, anticlinal folds, load casts, and flame structures) are likely triggered by seismic shocks. The inferred influence of seismic activity results from rifting and rapid subsidence of basin-fill during the Cretaceous. Some of these soft-sediment deformation structures (SSDS) are induced by fluidization and liquefaction triggered by rapid sedimentation within tectonically active settings, as well as density variations illustrated by local occurrence of load casts with weak lateral extensions. (3) The synsedimentary features (joints, faults, filled fractures) are related to local stress triggered by gravitational sliding, because the fractures were filled by unconsolidated clastic materials.
\end{abstract}

\section{Introduction}

Sediments transported and deposited within sedimentary basins may undergo modifications during lithification and diagenesis while still in their weak (soft) state. These modifications may create sedimentological signatures such as load casts, flames, flexures, and dish-like and fold structures which help in tracing their origin, causes, and geotectonic settings of the sedimentary basin. According to $[1,2]$, these modifications may be related to gravitational effects, fluid movement, density contrast, sediment instability, and overloading influence by mechanism of fluidization or liquefaction. Primary occurrences of soft-sediment deformation structures (SSDS) within sedimentary environments are seismically induced (Moretti and Pedro 2016) [1]. Fluidization and liquefaction within sedimentary environment take place during seismic shocks which influence other local effects [1]. Yang et al. (2016) [3] suggested a wide variety of geological agents as triggering mechanisms for SSDS such as liquefaction or fluidization by earthquake-induced shock waves, adjustment to gravity in successions with reversed density gradients, shear stress, sudden overloading by masstransported sediments, slumping or slope failure, large-scale deformations resulting from tectonic activity, and intermediate or small size SSDS commonly result from exogenic processes such as glaciotectonism and overburden-induced diapirism.

Classification of deformation structures by [4] within sedimentary formations is linked to morphological features such as load casts, flame structures, clastic dykes, disturbed laminitis, slumps, recumbent folds, and sedimentary faults $[5,6]$. Faults occurring within sedimentary environments may be either synsedimentary or postsedimentary. According to Benard (2002) [7], synsedimentary faults are characterized by filled fault planes (fault traces filled with correlative deposits) and do not cut all the formations of a stratigraphic 


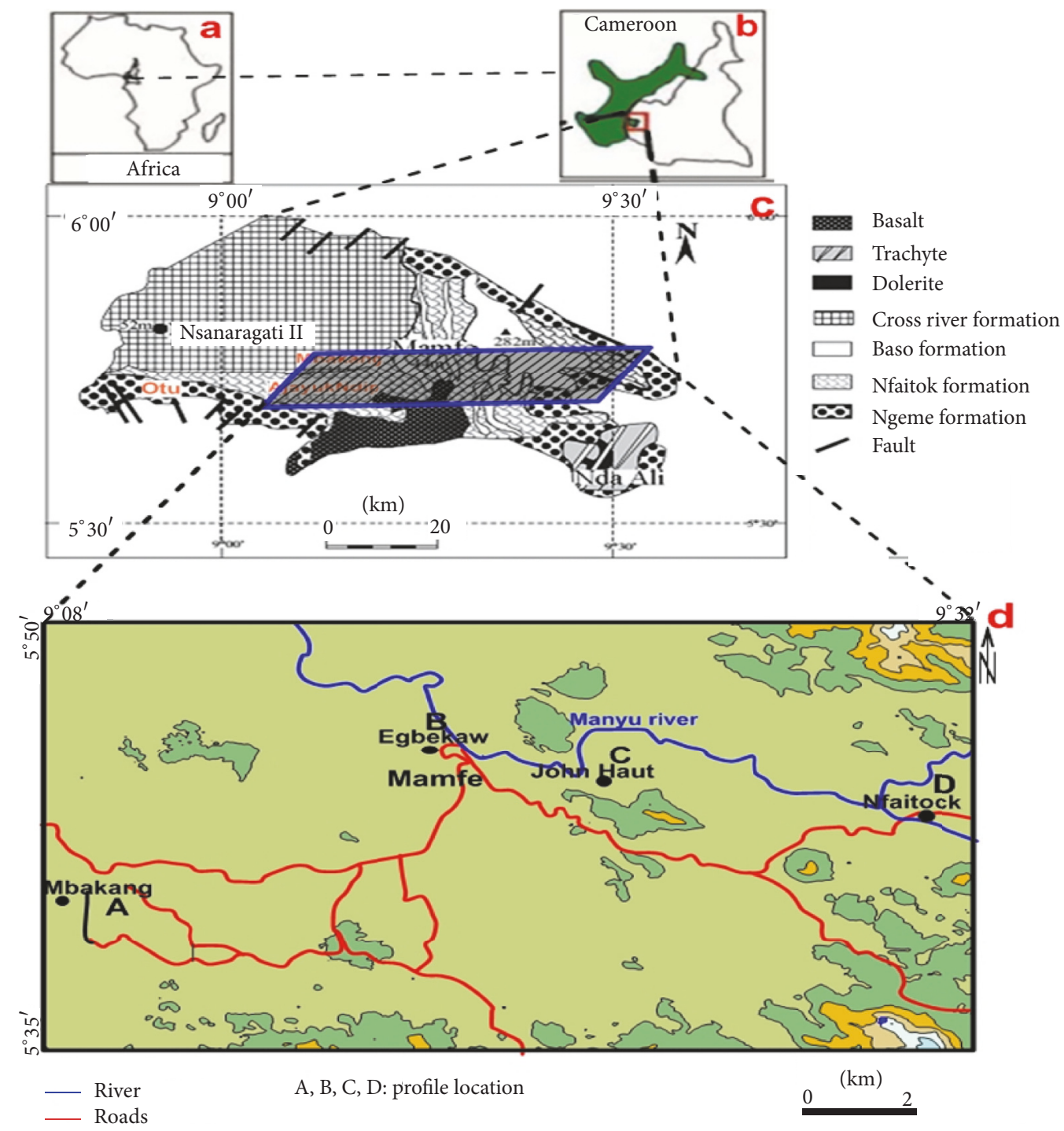

Figure 1: (a) Map of Africa showing the location of Cameroon; (b) map of Cameroon showing the Benue trough and the Mamfe Basin; (c) simplified geologic map of the Mamfe Basin [8] showing the study areas; (d) sketch location map of investigated site.

succession, whereas postsedimentary faults display opposite characteristics to the former.

The aim of studying soft-sediment in the Mamfe Basin is to (1) identify the different inherited deformation structures, (2) interpret and discuss the genetic mechanisms of deformation using data collected from the field, and (3) propose the most likely mechanism responsible for the genesis of clastic dykes and soft-sediment deformation structures.

\section{Study Area}

The Mamfe Basin is located in the Manyu Division, SouthWest Region of Cameroon in Africa (Figures 1(a) and 1(b)). This basin covers an area of $130 \mathrm{~km}$ length and $60 \mathrm{~km}$ width [2]. Its fluviolacustrine sedimentary infill (Figure 1(c)) has been dated in the late Cretaceous age [9-11]. Sedimentary lithologies are exposed along rivers (around Munaya and
Nchemba), and the beds are frequently cut by magmatic dykes of basaltic and doleritic compositions. These magmatic rocks (dykes) have been attributed to the Tertiary age by many authors; [11, 12]. The Cretaceous sedimentary formations (Cross river, Nfaitok, Baso, and Ngeme; see Figure 1(c)) are thought to rest on a Precambrian granitic-gneissic basement [12].

Tectonically, the Mamfe Basin is thought to have been formed during Late Jurassic-Early Cretaceous as a result of basement rifting associated with the reactivation of an E$\mathrm{W}$ trending mylonite zone within the Pan-African basement [12]. The rift propagated along existing lines of weakness and broadened during the Upper Jurassic time [12]. Rifting in this basin is believed to have been accompanied by rapid subsidence due to thermal recovery of the lithosphere following a thermal disturbance that led to stretching and thinning of the crust beneath the basin [13]. 


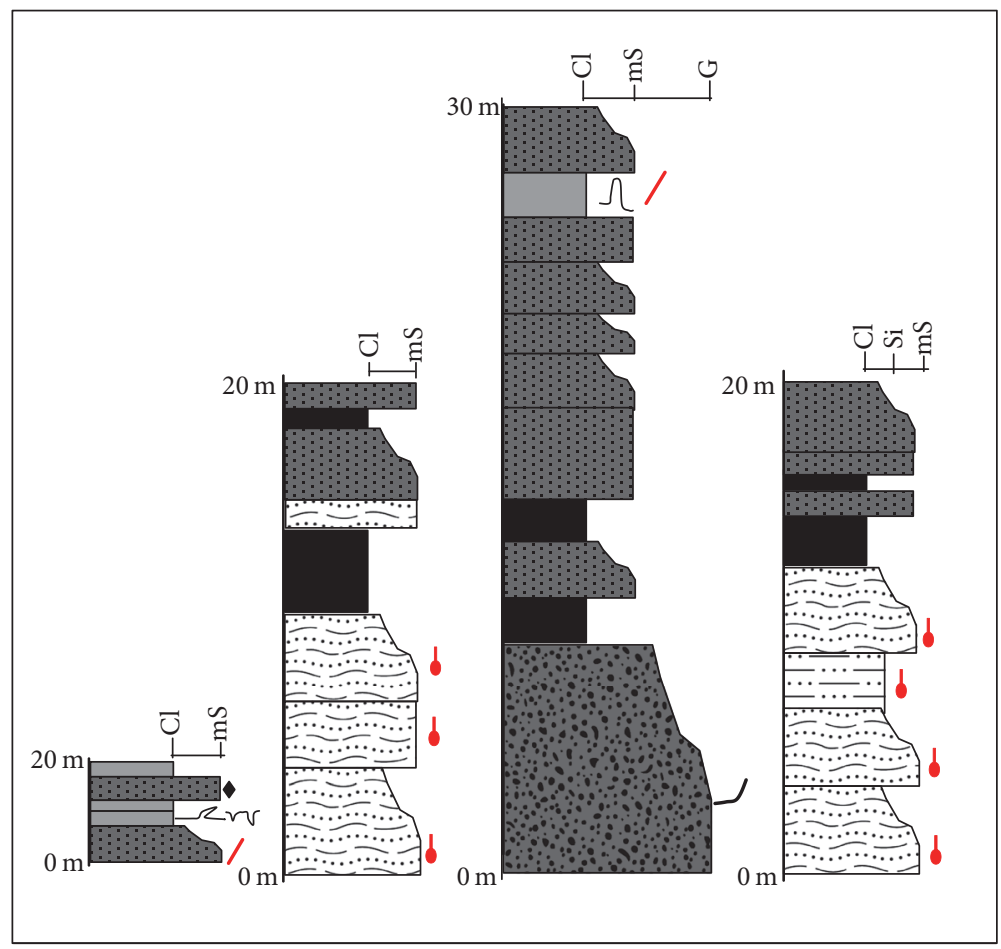

\begin{tabular}{ll}
\hline$::$ Medium grained sandstone \\
Shale \\
\hline & Mud rock \\
\hline.- & Silty shale \\
$\mathrm{Cl}$ & Clay \\
$\mathrm{mS}$ & Medium sandstone
\end{tabular}

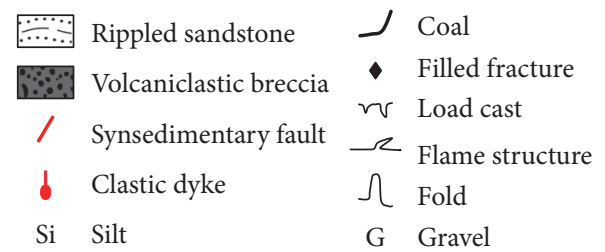

FIGURE 2: Detailed stratigraphic columnar sections of the Cretaceous sediments showing the different lithofacies and associated clastic dykes and soft-sediment deformation structures.

The sedimentary Mamfe Basin is a south-eastern trending Cretaceous rift basin that bifurcates off the Benue trough and is linked to the West and Central African Rift System (WCARS) [8]. Like the rest of the WCARS, the Mamfe Basin is linked to the opening of the South Atlantic Ocean. Its formation was associated with the breaking up of Gondwanaland (southern supercontinent) and subsequent separation of South America plate from Africa plate [1].

\section{Materials and Methodology}

Soft-sediment deformation and clastic dykes were studied on outcrops locations found in Mbakang, John Hault, Egbekaw, and Nfaitok (Figure 1(d)). Graphic logs were drawn to illustrate the vertical sequence variation of lithofacies and their relative thicknesses. Structural orientations were determined using clinometers following standard procedures [14]. Geographical coordinates of each visited locality were recorded with a Garmin GPS (model 76TM). The GPS coordinates were later transferred onto a Minna geodesic datum georeferenced base map of the Mamfe Basin using Global Mapper 13. Suffer 11 was used to draw the location map. Lithofacies assemblage and facies analysis was based on observable variations of physical parameters (grain size, color, sedimentary structures) and the use of a hand lens for fine-grained lithofacies using physical visible variation, color parameter, and grain size technique referring to the grain size scale and with the use of hand lens. Dilute hydrochloric acid was used to test the presence of carbonates. The above parameters have been used to construct summary lithostratigraphic columns within the study area (Figure 2) using suffer 11 and Adobe Illustrator cartographic software.

\section{Results}

4.1. Description of Clastic Dykes. Bulge clastic dykes of dark greyish medium grained carbonate clastic rock occur on top of surfaces in Nfaitok (Figure 3(a)) and a light grayish medium grained clastic rock at the surfaces in Egbekaw (Figure 3(b)). Locally, they rise $6-10 \mathrm{~cm}$ above the bedding planes of the bed-rocks and have a thickness of $11-15 \mathrm{~cm}$. A few of them are less than $7 \mathrm{~m}$ long while others extent to about $12-15 \mathrm{~m}$ at most. The bed-rocks are different from these clastic bulges in their grain size and color. The clastic dyke infill reacts vigorously with dilute hydrochloric acid and shows difference in strike direction. The clastic dykes 


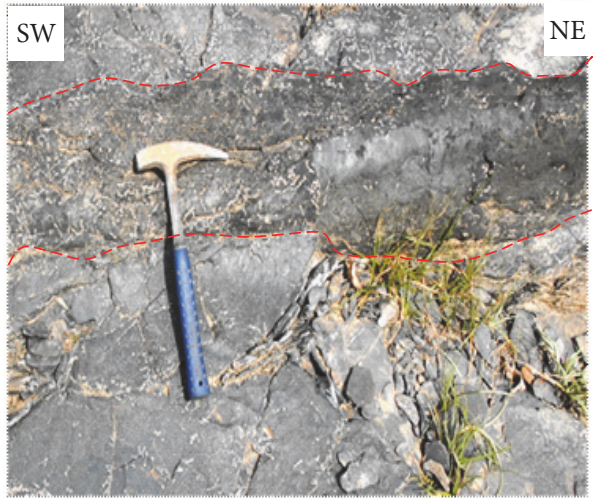

(a)

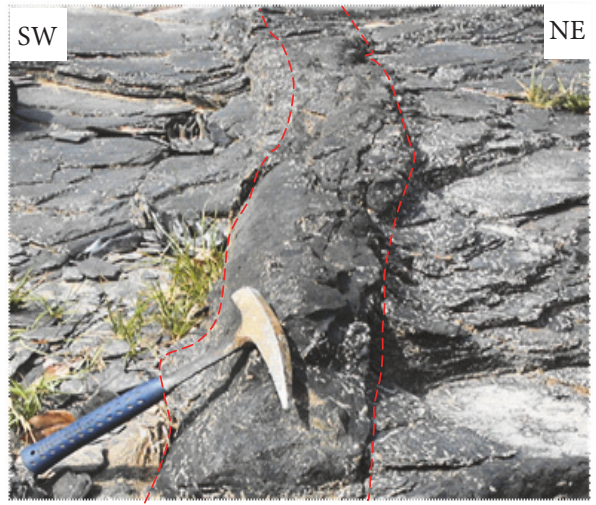

(b)

Figure 3: Photograph of a clastic dykes at Nfaitok. (a) Series of fractures of millimetric sizes seen at both sides of the clastic dykes. (b) The rocks at the contact with the clastic dyke are platy with upwards bulges.

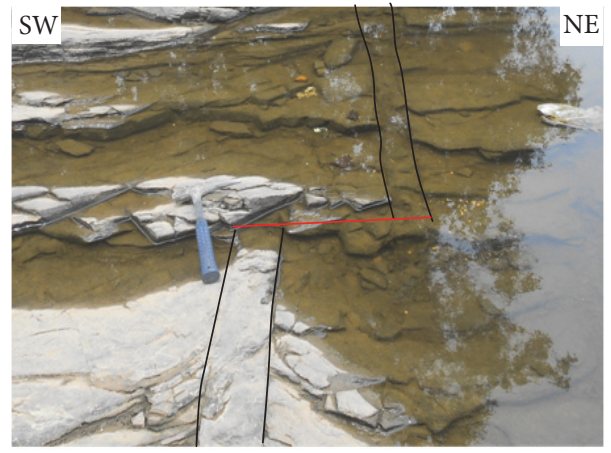

(a)

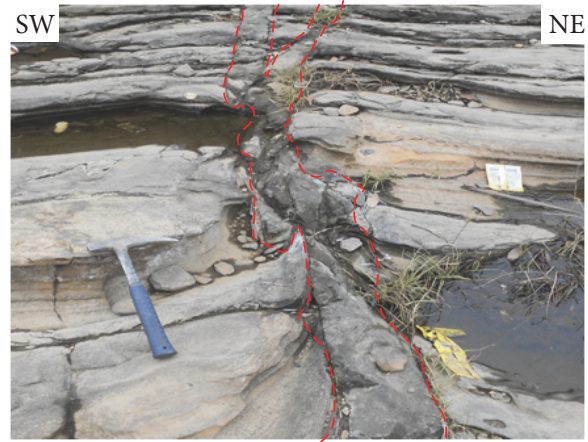

(b)

Figure 4: Photograph of a clastic dyke at Egbekaw cross cutting a silty shale bed showing (a) a normal dextral fault, (b) normal sinistral fault with fault plane filled by clastic dykes.

were found at Nfaitok (Figure 3) strikes $\mathrm{N} 120^{\circ} \mathrm{E}-\mathrm{N} 150^{\circ} \mathrm{E}$, but at Egbekaw (Figure 4) bulges strike $\mathrm{N} 80^{\circ} \mathrm{E}-\mathrm{N} 90^{\circ} \mathrm{E}$. These dykes are parallel to each other, branch to a specific direction (SW-NE), and discordant to the bedding plane of a finegrained shaly bed-rocks (Figure 3).

4.2. Soft-Sediment Deformation Structures. Soft-sediment deformation structures occur at Mbakang and John Hault quarries. These areas expose weakly consolidated mudrock interbedded with friable sandstones. Locally, beds dip $20^{\circ}$ towards the SW (Figure 5) and $45^{\circ}$ to the N (Figure 6(a)). These structures appear locally with a weak lateral extension ranging from $5 \mathrm{~m}$ to $15 \mathrm{~m}$.

At John Hault (Figure 5), a layer of weakly consolidated mudrock is deformed by anticlines with symmetrical to asymmetrical limbs. The folding is specific in the lower part of the profile and fades progressively towards the top of the profile (Figure 5). Layers of the upper parts are composed of uncharacterized weathered materials which are completely undisturbed. The folded layer at one point is displaced by a NW-SE striking high angle fault. This fault extents to the underlying sediments layer, but its continuation downward cannot be evaluated. The normal fault plane is filled with uncharacterized clastic material which also stains part of the hanging wall.

At Mbakang, the occurrence of soft-sediment deformation structures is observable at a smaller scale. Soft-sediment deformation structures like flexures, load casts, and flame structures are seen occurring in slightly clay enriched layers (Figure 6(b)). Large fractures of about $6-8 \mathrm{~cm}$ width and smaller fractures of less than $3 \mathrm{~cm}$ width are seen filled with unconsolidated sandy facies (Figure 6(c)). Sandy clay lens structures (Figures 6(a) and 6(b)) are displaced by microfaults with variable displacement magnitudes. These faults planes have three different orientations (NW-SE, NNW-SSE, and $\mathrm{E}-\mathrm{W}$ ) representing low to high angle faults. These fault planes are also filled with uncharacterized clastic material like the one found at the John Hault quarry.

\section{Discussion}

5.1. Origin of Clastic Dykes in the Mamfe Basin. Clastic dykes can be extrusive, sugtructive, or Neptunian depending on their origin and factor mechanisms that lead to their formation [15]. Clastic dykes at Egbekaw and Nfaitok are recognized on the basis of their obvious difference with 


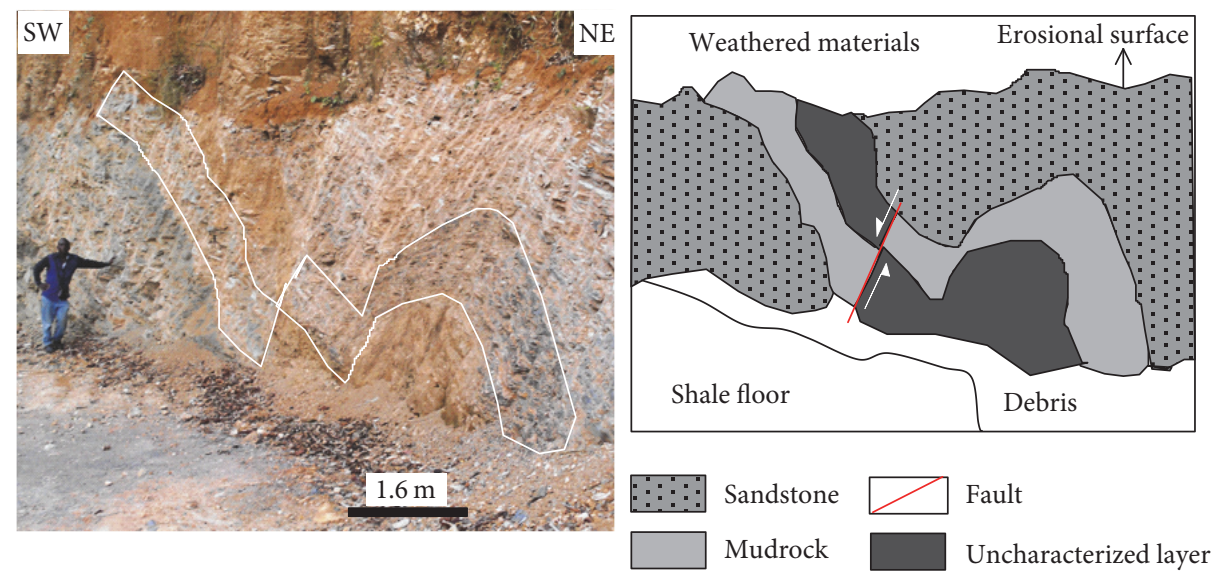

FIGURE 5: Field view and line drawing of exposed section in the John Hault quarry where sandstone, silty shale, mudrock, and uncharacterized reddish brown material are observable. Folded and normal faulted mudrock beds occur.

the bed-rocks. Bulge structures displayed by these dykes indicate they may have been forced upward to the surface by strong shocks through cracks created at the time of their expulsion (intrusion), when they were still in a fluidized state. These dykes react vigorously with dilute $\mathrm{HCl}$ indicating the presence of carbonate cements. One could therefore suggests that their compacted nature is related to carbonate cements as time is not a prime factor of lithification as compared to cementing material. Hydrocarbon expulsion and extensional fractures are absent in this locality. Open fissures (extensional cracks) created by tectonics may have been filled by weathered transported detritic material forming the clastic dykes (Figure 7). However, the evidence supporting this assertion is invalid in the studied area as no clastic dykes have been seen cutting the Precambrian basement formation and the funnel structures are absent [15]. Consequently, these clastic dykes may have originated from magmatic processes which generated strong shocks that forced the water-mixed clastic material to move upward to the surface before being lithified (Figures 7 and 8). This point is supported by the intense upward shearing of the shale beds at the contact with the clastic dykes. The concomitant occurrence of Tertiary volcanic magmatic dykes (Munaya and Nchemba river) and the presence of coaly layers mixed with volcaniclastic materials were found tens of kilometers away from the studied areas.

5.2. Origin of Soft-Sediment Deformation Structures in the Mamfe Basin. Soft deformational structures affecting sedimentary rocks may develop during and after their deposition. These sediments in their fluid states may experience breakdown in the unstable grain fabric creating a pore fluid overpressure which may lead to the deformation and intrusion of the overburden [16]. Fluidized (water-mix) sediments underlying an overpressured superficial material (in the case of Mbakang and John Hault) may be affected by disequilibrium compaction as a result of uneven distribution of loads and density variations [10]. Disequilibrium compaction resulting from uneven distribution of loads and density variations will affect most parts carrying a high density of the overburden material leading to the formation of folds, flexures (stretching), foliations, load casts, and flame structures. Soft sediments researchers $[1,7]$ suggest fluidization driven by gravitational forces as trigger of the formation of soft-sediment deformation features.

The genetic classification of SSDS based on whether or not seismic activity has promoted their formation remains a problem under survey in field studies. Török et al. (2017) [17] and Van Loon (2014) [18] concluded that fluidization and liquefaction may play a major role in the genesis of SSDS with little exposure to seismic shocks. This could be true in the cases of the John Hault anticlinal structure resting on a volcaniclastic breccia layer mixed with coal. In the case of Mbakang, evidence of seismic influence is faint with the occurrence of baked margins in brecciated, sheared, and boudinized magmatic dyke with a strike of $\mathrm{N} 60^{\circ} \mathrm{E}$ in Ajayuk Ndip, some $3 \mathrm{~km}$ to the north. This is a magmatic event linked directly to extensional stress.

The above evidence could only suggest double effects on the origin of SSDS, with the major fluidization and liquefaction being triggered by rapid sedimentation, uneven distribution of load, and grain variation density followed by the effects of seismic shocks. The local occurrence or weak lateral extension (10-20 m) of the SSDS (load casts, flame structures, anticlinal folds) in the basin may suggest that these structures are likely unrelated to seismic activity. Accordingly, $[18,19]$ states that "non seismic originated SSDS have weak lateral extensions." On the other hand, the rifting and rapid subsidence (Late Jurassic-Early Cretaceous) during the formation of the Mamfe Basin may have been influenced by seismic activity that triggered the occurrence of softsediment deformation structures. According, to Moretti and Pedro (2016) [1], SSDS within sedimentary environments are triggered by seismic shocks or are seismically induced influencing other local effects.

Njoh et al. (2015) [10] point out that the Mamfe Basin has a fluviolacustrine depositional environment. A cyclic change in the fluvial deposition of sandstones (arkose) to a lacustrine shale environment (Figure 2) may have played a vital role in the formation of some SSDS found in the study area. In particular, the rapid deposition of sand 

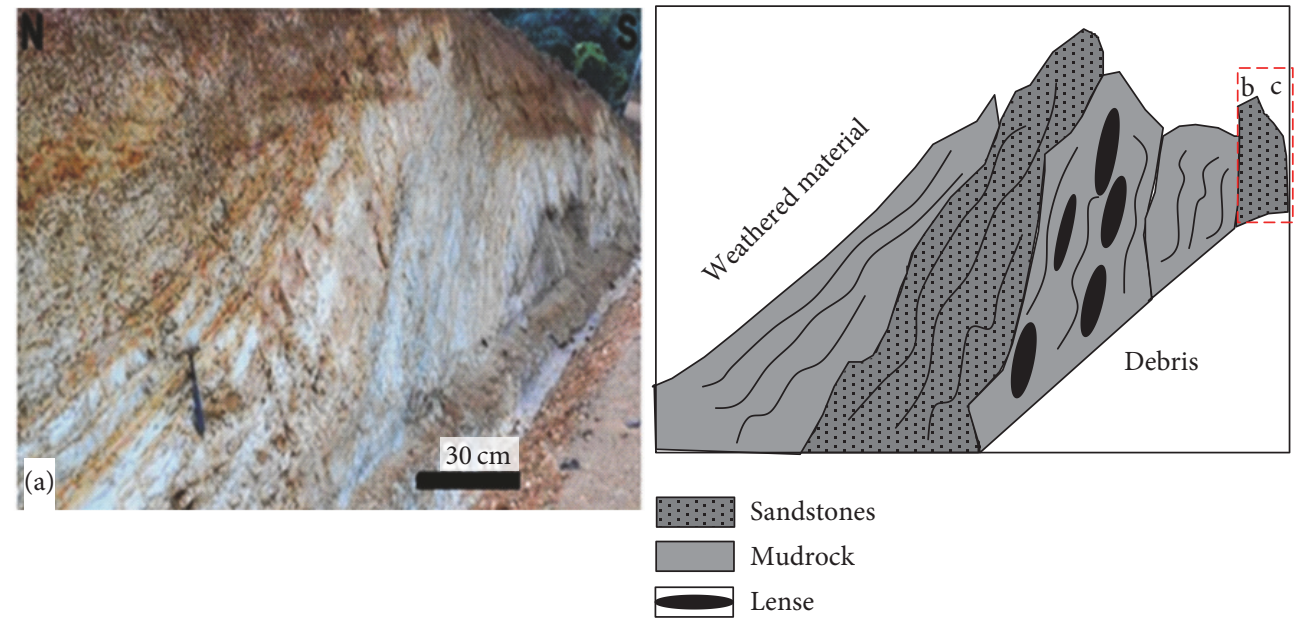

(a)
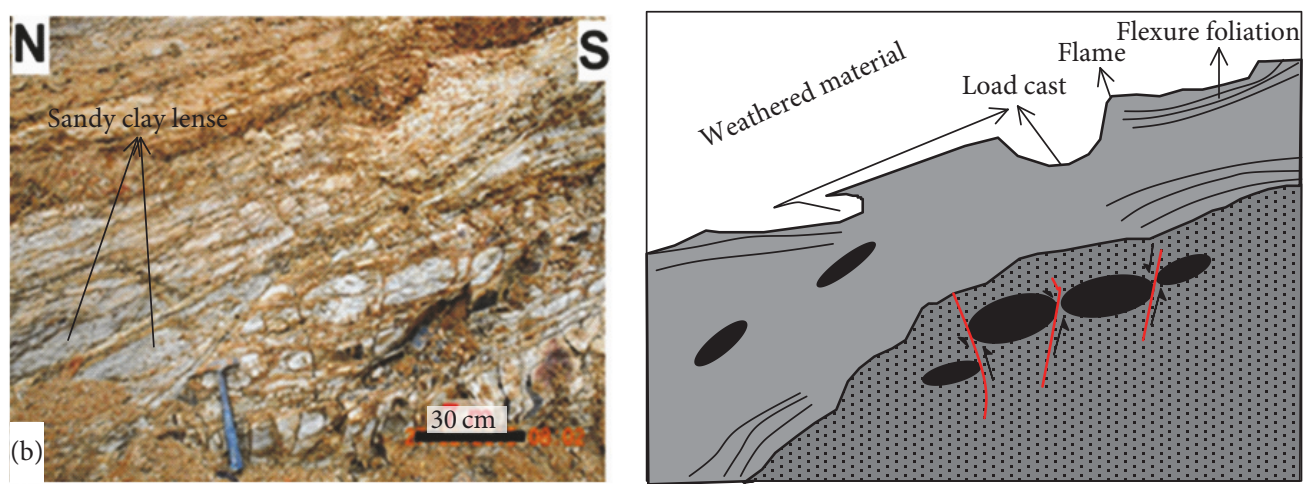

(b)
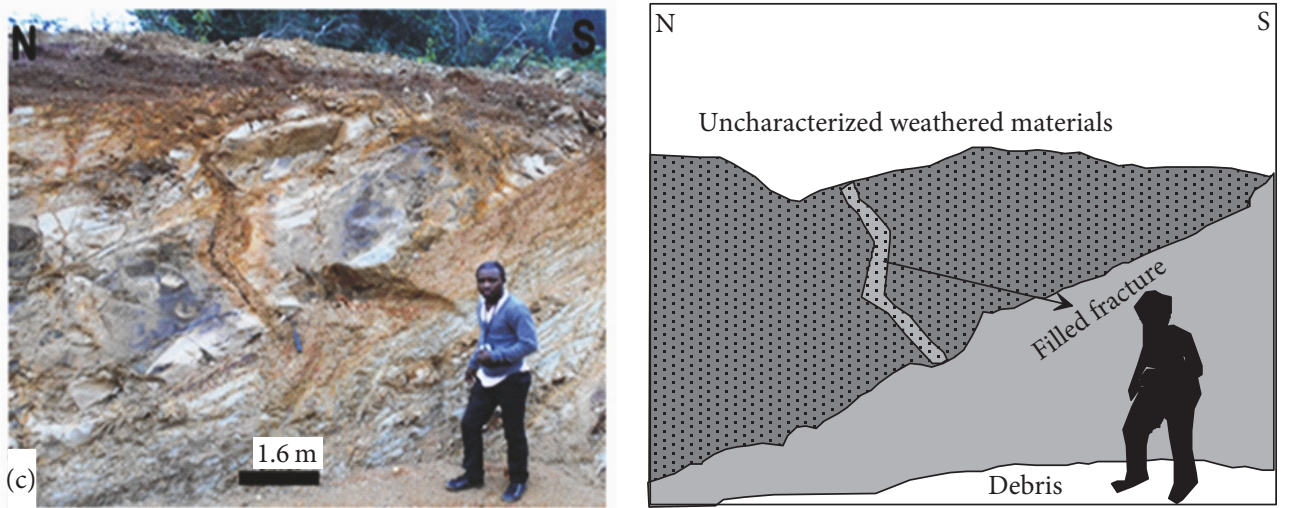

(c)

Figure 6: (a) Field view and line drawing of exposed section in the Mbakang quarry with stretching of small clayey layers within the beds. (b) Detailed view and line drawing of the exposed section where sandstone is pinched out to the southern direction showing large and small vertical fractures filled with clayey sandy materials. (c) Detailed view and line drawing of the exposed section where the soft mudrock layer displays a flexure, load cast, and flame structure with lenses of clay rich sandy facies while the sandy beds display faults with variable orientations and displacement magnitudes.

produces a reverse density gradient which destabilizes and possibly fluidizes the underlying sediments. This destabilization causes synsedimentary subsidence which facilitates ductile deformation of the water-mix sand sediments. This hypothesis is supported by the observation that this basin is formed by extension accompanied by rapid subsidence [13].

The occurrence of synsedimentary structures (faults, joints, filled fractures) cutting the deformed beds may suggest that the extensional fault activity produced seismic shocks 


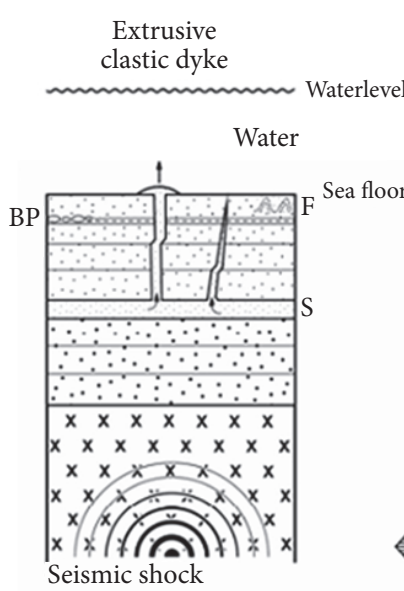

(a)

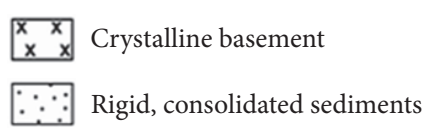

$\begin{gathered}\text { Sugtrusive } \\ \text { clastic dyke }\end{gathered}$
$\begin{gathered}\text { Neptunian } \\ \text { dyke }\end{gathered}$

Water

Water

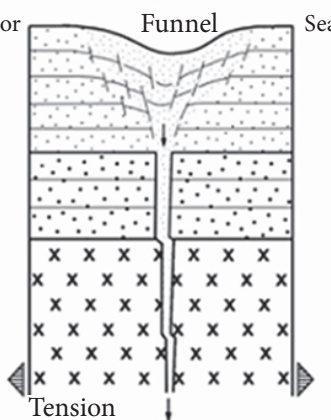

(b)

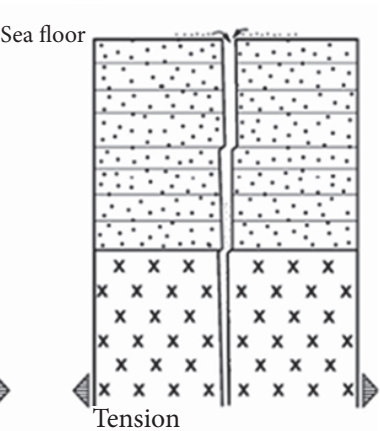

(c)
Soft, unconsolidated sediments
Liquidized sediments dykes and source beds

Figure 7: Diagram showing classification of clastic dykes. (a) Extrusive clastic dykes occurring in Cretaceous formation originating from seismic shocks. (b) Sugtrusive clastic dykes form from tectonics. (c) Neptunian dykes form from extensional tectonics [6].

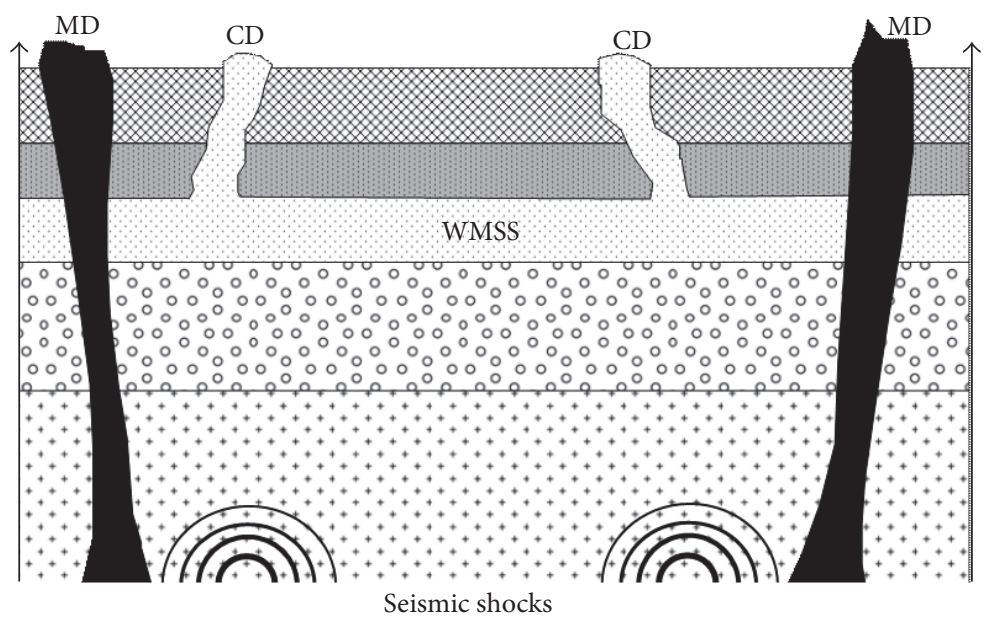

\begin{tabular}{l} 
Mertiary formation \\
Magmatic dyke \\
Cretaceous formation \\
Silty shale \\
\hline$\vdots: \vdots$ Carbonated sandstone \\
\hline 00 Cater-mix sand sediment \\
\hline \\
\hline
\end{tabular}

FIGURE 8: Schematic diagram of clastic dykes occurrences in relationship to the geologic setting of the Mamfe Basin, WMSS: water-mix clastic materials, MD: magmatic dyke, CD: clastic dykes.

that mobilized the fluidized sediments creating wall cracks, which were later filled by material, and minor displacement of layers. However, the above reconstruction is uncertain as (1) the continuation at depth of these synsedimentary structures cannot be evaluated and (2) none of the materials filling the fractures are well consolidated.
According to Török et al. (2017) [17], the origin of the filled fractures, joints, and faults within sedimentary formations has a question mark whether they were formed by tectonic forces or due to gravitationally controlled slope movements. Gravity factors may be considered in the case of this study since debris made of fine clastic materials 
particularly prone to gravity sliding is found at the basement of the profiles, filled fractures, and fault planes.

The separation of deformed beds from the overlying undeformed layer may indicate density and rheological differences [5].

\section{Conclusions}

(1) Information from synsedimentary deformation structures reveal two major stratigraphic units: a lower deformed unit, unconformably overlying by a nondeformed unit.

(2) Deformed structures (flexures, sheared foliations, anticlinal folds, load casts, and flame structures) are likely triggered by seismic shocks. The suggested influence of seismic activity would result from rifting and rapid subsidence of the basin-fill during the Cretaceous. Some of these SSDS (load casts and flame structures) are induced by fluidization and liquefaction triggered by rapid sedimentation within a tectonically active setting, as well as density variations illustrated by the local occurrence of load casts with weak lateral extensions.

(3) Synsedimentary features (joints, faults, filled fractures, and filled fault planes) are likely related to local stress induced by gravitational sliding. However it cannot be excluded that tectonic stresses could have also played a role in the formation of the fractures, particularly if some of them were not filled by unconsolidated clastic material.

(4) The clastic dykes are extrusive features as material was obviously intruded from below, exploiting fissures that opened during the intrusion. The genesis of clastic dykes appears to have been influenced by tectonic-volcanic processes that created fissures and generated seismic shocks promoting the fluidization of sediments at depth and their upward movement to the surface prior to lithification. This conclusion is supported by the fact that no clastic dykes have been observed to cut the Precambrian basement formation of the Mamfe Basin.

\section{Conflicts of Interest}

The authors declare that there are no conflicts of interest regarding the publication of this paper.

\section{References}

[1] M. Moretti and A. Pedro, "The environmental significance of soft-sediment deformation structures: key signatures for sediemntary and tectonic precesses," Journal of sedimentary geology, vol. 344, pp. 1-4, 2016.

[2] G. I. Alsop and S. Marco, "Soft-sediment deformation within seismogenic slumps of the Dead Sea Basin," Journal of Structural Geology, vol. 33, no. 4, pp. 433-457, 2011.

[3] R. Yang, A. J. van Loon, W. Yin, A. Fan, and Z. Han, "Softsediment deformation structures in cores from lacustrine slurry deposits of the Late Triassic Yanchang Fm," Geologos, vol. 22, 3, pp. 201-211, 2016.

[4] C. Montenat, P. Barrier, P. Ottd'Estevou, and C. Hibsch, "Seismites: An attempt at critical analysis and classification," Sedimentary Geology, vol. 196, no. 1-4, pp. 5-30, 2007.

[5] G. Owen and M. Moretti, "Identifying triggers for liquefactioninduced soft-sediment deformation in sands," Sedimentary Geology, vol. 235, no. 3-4, pp. 141-147, 2011.

[6] H. Scholz, D. Frieling, and M. Aehnelt, Synsedimentary Deformational Structures Caused by Tectonics and Seismic Events Examples from the Cambrian of Sweden, Permian and Cenozoic of Germany, Evgenii Sharkov, Ed., New Frontiers in Tectonic Research - General Problems, Sedimentary Basins and Island Arcs, 2011

[7] B. D. Benard, in Sedimentary Geology: Sedimentary Basin, Depositional Environment Petroleum Formations, Institute de francais du petrole, France, 3rd edition, 2002.

[8] J. T. Eyong, P. Wignall, W. Y. Fantong, J. Best, and J. V. Hell, "Paragenetic sequences of carbonate and sulphide minerals of the Mamfe Basin (Cameroon): Indicators of palaeo-fluids, palaeo-oxygen levels and diagenetic zones," Journal of African Earth Sciences, vol. 86, pp. 25-44, 2013.

[9] M. G. Abolo, "Geology and Petroleum Potential of the Mamfe Basin, Cameroon, Central Africa," Africa Geosciences Review, pp. 65-77, 2008.

[10] O. A. Njoh, M. B. Nforsi, and J. N. Datcheu, "Aptian-late cenomanian fluvio-lacustrine lithofacies and palynomorphs from mamfe basin, southwest cameroon, west africa," International Journal of Geosciences, vol. 06, no. 07, pp. 795-811, 2015.

[11] Y. LeFur, Special report on corundum gem research. Cretaceous basement. Mission. Mamfe. YAO 666A8. Archives BRGM. DMG/MINEE (infrench), 1965.

[12] D. Wilson, Notes on the Geology of the Mamfe Division, Cameroon SW Province.Occasional papers.Geologic Survey of Nigeria no6, 1928.

[13] H. N. Ajonina, O. A. Ajibola, and E. C. Bassey, "The Mamfé basin, SE Nigeria and SW Cameroon: a review of the basin filling model and tectonic evolution," Journal of the Geoscience Society of Cameroon, vol. 1, no. 1, pp. 24-25, 2001.

[14] L. C. Angela, in Geological Field Techniques, pp. 11-16, Blackwell Science Publishing, Oxford, 1st edition, 2010.

[15] H. Scholz, D. Frieling, and K. Obst, "Funnel structures and clastic dykes in Cambrian sandstones of southern Sweden Indications for tensional tectonics and seismic events in a shallow marine environment," Neues Jahrbuch fur Geologie und Palaontologie - Abhandlungen, vol. 251, no. 3, pp. 355-380, 2009.

[16] R. J. H. Jolly and L. Lonergan, "Mechanisms and controls on the formation of sand intrusions," Journal of the Geological Society, vol. 159, no. 5, pp. 605-617, 2002.

[17] A. Török, M. Andrea, C. Hannes, K. Sandor, F. Laszlo, and S. Rudy, Geobody architecture of continental carbonates: "Gazda" travertine quarry (Sütto, Gerecse Hills, Hungary), Quaternary International, 2017.

[18] A. J. Van Loon, "The life cycle of seismite research," Geologos, vol. 20, no. 2, pp. 61-66, 2014.

[19] S. Sarkar, C. Adrita, B. Santanu, A. J. van Loon, and K. B. Pradip, "Seismic and non seismic soft-sediment deformationstructures in the Proterozoic Bhander Limestone, central India," Geologos, vol. 20, pp. 89-103, 2014. 

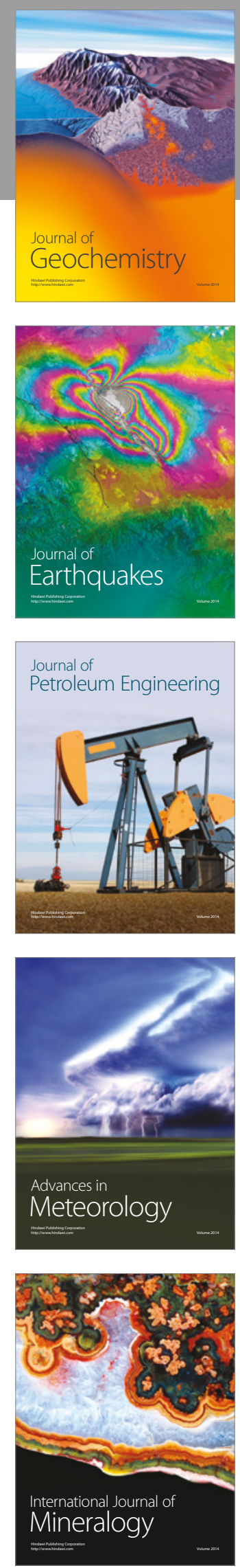
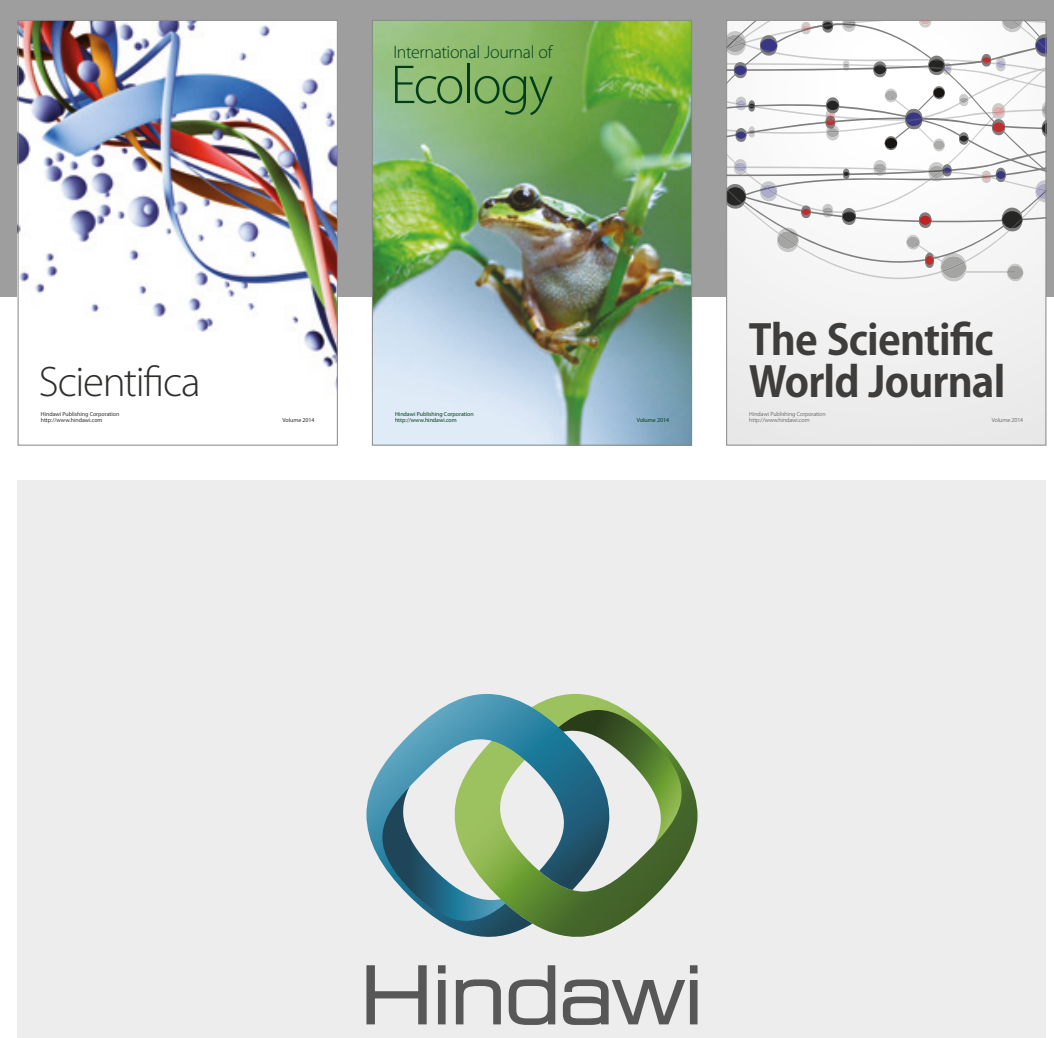

Submit your manuscripts at

https://www.hindawi.com
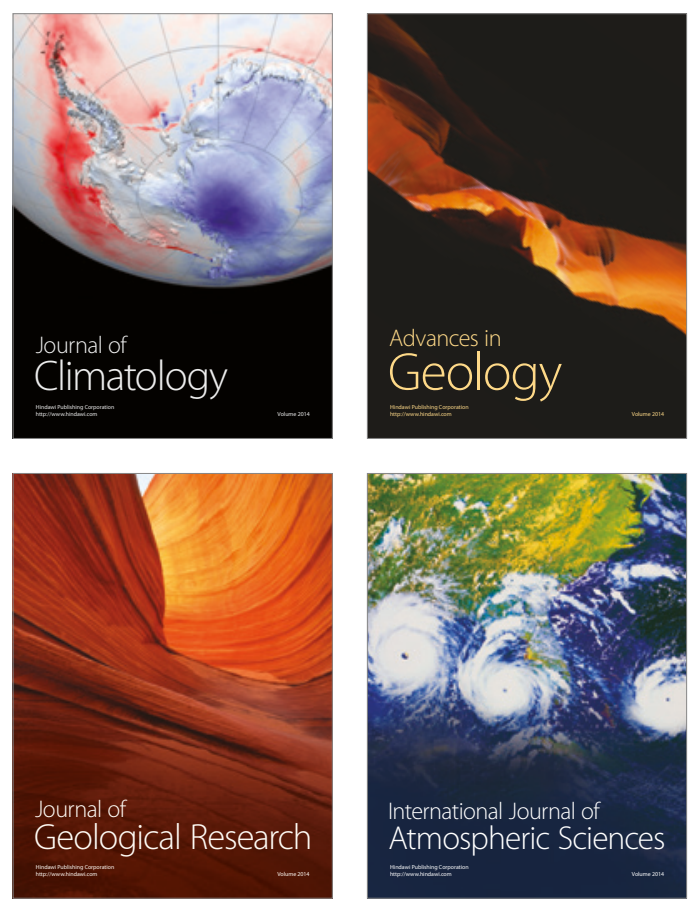

The Scientific

World Journal
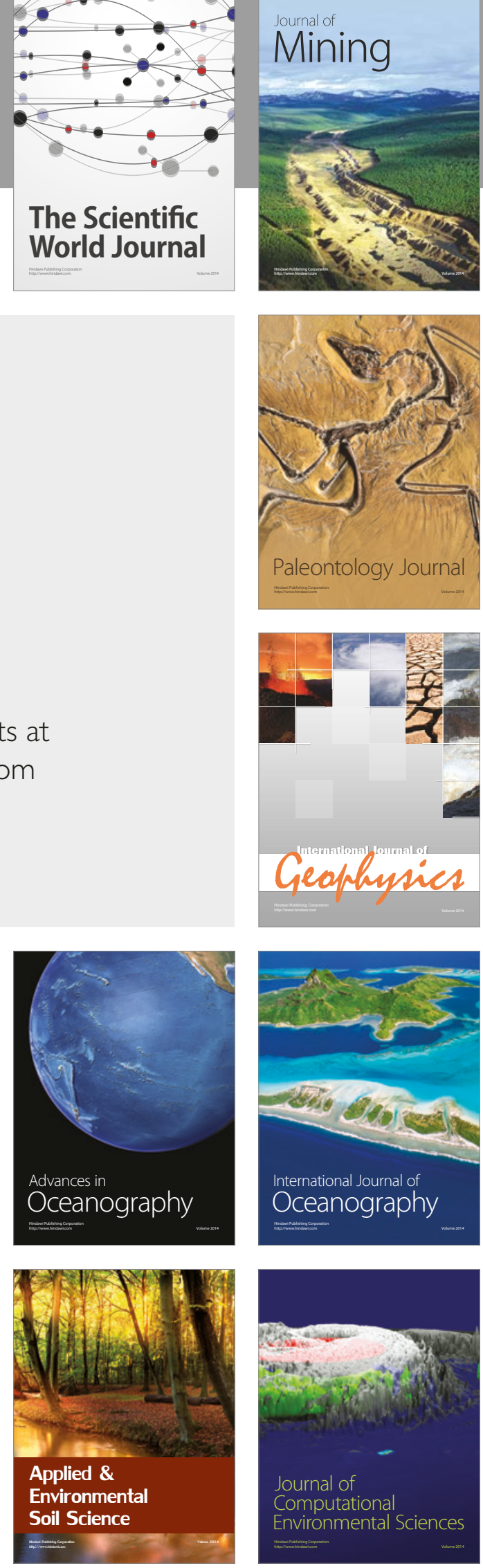